\title{
The notion of the concept "mother" in proverbs (on the proverbs in Uzbek, Russian and German)
}

\author{
Tagaeva Sayyora Ulashevna ${ }^{1}$ \\ ${ }^{1}$ Doctorate researcher, Samarkand State University, Samarkand, Uzbekistan \\ Email:tagaeva_s@umail.uz
}

\begin{abstract}
This article provides a linguistic and cultural comparison and analysis of the peculiarities of proverbs in the course of work on the concept of "mother" in Russian, German and Uzbek languages.

Keywords: concept, cognitive, linguoculturology, paremia.

\section{INTRODUCTION}

One of the most important tasks of contemporary linguistics is to compare and deeply study the interrelationship, culture and language of mother tongue and learning. The main focus of the study of foreign languages is to focus on the linguistic wealth of the readers. It is advisable to use articles and stories in foreign languages to solve this problem. We know that the articles reflect the national character, mentality and traditions of the people. Therefore, expanding vocabulary by utilizing articles, fables, and specific cultural concepts is one of the most important methods of learning a language.
\end{abstract}

\section{MAIN PART}

This article discusses linguoculturologic analysis of the concept of "mother" and the comparison of proverbs in a number of languages. The proverbs are the spiritual richness and cultural heritage of the people for many years. Proverbs are a kind of legends. When analyzing family and family traditions and teaching methods in Russian and a number of languages, it is well known that the notion of mother is important in all languages [5.8].

1) Mother is valued for everyone.

In Uzbek: «Она- олам фахридир», «Бола хам она дейди, она хам она дейди», «Она дарахт, бола мева» ("Mother is proud", "The child calls a mother, mother calls her mother", "Mother is a tree, a child is a fruit") [3.317].

In Russian, «У кого есть матка, у того голова гладка», «нет такого дружка, как родная матушка».("Who has a mother, he has no headache ", "Mother is a real friend)" [5.50]

In German: "Die beste Amme ersetzt keine Mutter".

2) It is also a symbol of peace and tranquility in the linguistic tradition of the three languages.

In Uzbek: «Она мехрибон ота ғамгузор», «Она хаётнинг гули, бола унинг булбули», «Она оёғи билиан бешикни, кӯли билан рӯрзорни тебратар», «онали боланинг оғзи уйнар, онасиз боланинг куззи уйнар» ( "Mother is a loving mother carpenter", "Mother is a flower of life, child is her nightingale", "Mother cradles with her feet, her mouth grows", "mother's baby's mouth and child's eyes.")[3.316]

In Russian: -«Мать праведна- ограда каменная», «Сердце матери лучше солнце греет», «С матерью жить - ни скуки, ни горя не знать» (“The mother stronger than wall”, "Mother's heart is hot", "Life with mother life without boring" [5.50]

In German: "Ist eine Mutter noch so arm, so gibt sie ihrem Kinde warm".

3) It is known in the Uzbek, Russian and German legends that each mother values her child and cares for all her.

In Uzbek: «Онага боланинг олалиги йӯқ», «Боласи кууча кезар, онаси бағрин эзар», «Онангни яхшилигини бемор буллсанг биларсан» ("There is no alien mother for a child", "The child goes away, his mother is in pain" , "You know how good your mother when you are ill." [3,315] 
In Russian: «Для матушки ребёнок до ста лет дитёнок», «Всякой матери своё дитя мило» («Child is ever baby for mother», «Every bird loves his child»)

In German: "Muttertreu ist taglich neu", "Eine Mutter ist der einzige Mensch auf der Welt der der schon liebt bevor er dich kennt".

4) The more a good mother loves her child, the more severe she is and the more important it is to her upbringing.

In Uzbek, «Энаси тепган кулимнинг эти оғримас», «Боланинг куунгли далада, онанинг кӯнгли болада» ("My son's hurt does not hurt", "The child is in the field, mother looks for child")

In Russian: «Материнский гнев, что весенний снег, и много его падает, да скоро растает», «Матеренные побои не болят, мать их бия не бьет» ("Mother's anger as spring snow, it is lot but soon melt", "Mother's strike is painless")

In German: "Eine Mutter erreicht mehr als hundert Lehrer".

5) In German, Russian, and English, many thoughts are found not only on the appearance of the girl but also on her character and behavior.

In Uzbek: «Қиз берсанг отасига қараб бер, қиз олсанг онасига қараб ол», «Эшиги ёмоннинг уйига борма, онаси ёмоннинг қизини олма», «Отадан ууғил, онадан қиз», «Семиз қӯзининг гушти яхши, оқил онанинг қизи» ("Marry your daughter according to guy’s father, marry your son according to the mother"," Don't go to the house of the bad, do not take the daughter of the bad mother", "The best daughter of a brave young woman.")

In Russian: По матери и дочь», «Если хочешь узнать, какой будет невеста через много лет, посмотри на её мать»(«as a mother as a daughter», «if you want to know the future of the girl look at her mother»)

In German: "Die Tochter einer guten Mutter wird die Mutter einer guten Tochter", "Wie die Mutter, so die Tochter".

6) It is possible to find many proverbs in the linguistic of three languages about respect and value for mother.

In Uzbek, «Онасини суйганнинг боласини суй», «Онангни сенда шунчалик кӯп хаққи борки, сен унга хар қанча яхшилик қилсанг хам камлик қилади», «Отасини оғритган эл ичида хор буллар, онасини ооритган парча нонга зор буллар», «Она - олам фахридир» ("Не is the mother of the one who loves his mother", "You have a mother so much about you, that you do not do anything good for her", "She is abominable in a painful state, her mother is hard for bread").

In Russian: Когда мать на земле обижают, бог на небе плачет»(«When mother is sad, the god is angry»)

In German: "Man hat keine wichtigere Verbundete auf dieser Welt als seine Mutter", "Eine gluckliche Mutter ist fur die Kinder lehrreicher als hundert Lehrbucher uber Erziehung", "Mutter tragen ihre Kinder durch den Morgen, Kinder sollen ihre Mutter durch den Abend tragen ".

7) The role of mother in the upbringing of children is crucial.

In Uzbek, «Она сути билан кирмаган, тана сути билан кирмас», «Дарахтиги кӯра меваси, ота-онасига кура боласи», «Қизни онаси тийсин, уғилни отаси" (“mother does not come in with milk, does not enter with the milk of the body", "the fruit of the tree is the fruit of the earth, and the son of the child", "the mother upbring her daughter.") [4.159-б.]

In Russian: «Умел дитя родить, умей и научить», «Что с молоком матери не впитал, с коровьим не придёт», «Умная мать богатство семьи» ("When you bear, you have to upbring", "You ever look like your mother", "Wise mother is a treasure of family ")

In German: "Eine Mutter ist so viel Wert wie hundert Schulmeister".

8) When we analyze proverbs in German, Russian and Uzbek, we can see the negative attitude towards the stepmother.

In Uzbek: «Онанг уугай буллса, отанг уззингники эмас», «Онали етим гул етим, онасиз етим шум етим», «Отангни чорбоғида қолгунча, онангни уймоғида қол», «У гайнинг оти қурсин, саксовулнинг ути курсин" ("If your mom is stepmother, your father is not yours," " orphan with mother is flower orphan, orphan with father is a real orphan", "Keep up your mother until your father stayed in the garden.")[4.278] 
In Russian: «В лесу медведь, а в дому мачеха», «Достаток - мать, убожество - мачеха», «Мать гладит по шерети, мачеха - насупротив» («Bear in the forest, stepmother at home», «Motherrichness, stepmother-sadness», «Mother loves child, stepmother doesn't»)

In German: "Wenige sind wie Vater, niemand ist wie mutter".

\section{CONCLUSION}

The results of the linguistic analysis of proverbs in Uzbek, German and Russian indicate that in each of the three languages, one can find similarities. In the conclusion, it is important to note that the mother is priceless for every human being and her mother is ready for everything for her children.

\section{REFERENCES}

1. Maslova VA Cognitive Linguistics. M: Languages of Slavic culture, 2004, p. 93

2. Jeleznova Yu.V. Lingvocognitive and lingvocultural research of the concept "family". Thesis of dissertation: on awarding the PhD degree on philological sciences 10.02.19. Ijdevsk.: Udmurt State University, 2009. p. 27

3. Sh.Shomaksudov, Sh.Shorakhmedov. "Hikmatname". An explanatory dictionary of Uzbek folklore. Tashkent. 1990

4. Uzbek folklore proverbs. Chief editorial of publishing and printing stock company "Sharq". Tashkent. 2012

5. Poyon Bakirov. Proverbs encyclopedia of folklore. Tashkent. "Academprint" 2018. 